\title{
Assessment of total, ligand-induced peroxisome proliferator activated receptor $\gamma$ ligand activity in serum
}

\author{
Lariah Edwards, James Watt, Thomas F. Webster and Jennifer J. Schlezinger*
}

\begin{abstract}
Background: Humans are exposed to a complex mixture of environmental chemicals that impact bone and metabolic health, and traditional exposure assessments struggle to capture these exposure scenarios. Peroxisome proliferator activated receptor-gamma (PPARY) is an essential regulator of metabolic and bone homeostasis, and its inappropriate activation by environmental chemicals can set the stage for adverse health effects. Here, we present the development of the Serum PPARy Activity Assay (SPAA), a simple and cost-effective method to measure total ligand activity in small volumes of serum.
\end{abstract}

Methods: First, we determined essential components of the bioassay. Cos-7 cells were transfected with combinations of expression vectors for human PPARY and RXRa, the obligate DNA-binding partner of PPARY, along with PPRE (DR1)driven luciferase and control eGFP reporter constructs. Transfected cells were treated with rosiglitazone, a synthetic PPARY ligand and/or LG100268, a synthetic RXR ligand, to characterize the dose response and determine the simplest and most efficacious format. Following optimization of the bioassay, we assessed the cumulative activation of PPARY by ligands in serum from mice treated with a PPARy ligand and commercial human serum samples.

Results: Cos-7 cells endogenously express sufficient RXR to support efficacious activation of transfected PPARY. Cotransfection of an RXR expression vector with the PPARY expression vector did not increase PPRE transcriptional activity induced by rosiglitazone. Treatment with an RXR ligand marginally increased PPRE transcriptional activity in the presence of transfected PPARY, and co-treatment with an RXR ligand reduced rosiglitazone-induced PPRE transcriptional activity. Therefore, the final bioassay protocol consists of transfecting Cos-7 cells with a PPARY expression vector along with the reporter vectors, applying rosiglitazone standards and/or $10 \mu \mathrm{L}$ of serum, and measuring luminescence and fluorescence after a $24 \mathrm{~h}$ incubation. Sera from mice dosed with rosiglitazone induced PPRE transcriptional activity in the SPAA in a dose-dependent and PPARY-dependent manner. Additionally, human serum from commercial sources induced a range of PPRE transcriptional activities in a PPARY-dependent manner, demonstrating the ability of the bioassay to detect potentially low levels of ligands.

Conclusions: The SPAA can reliably measure total PPRE transcriptional activity in small volumes of serum. This system provides a sensitive, straightforward assay that can be reproduced in any cell culture laboratory.

Keywords: Metabolism disrupting compounds, PPARY, Human serum, Mixtures

\footnotetext{
* Correspondence: jschlezi@bu.edu

Department of Environmental Health, Boston University School of Public

Health, 715 Albany Street, R-405, Boston, MA 02118, USA
}

(c) The Author(s). 2019 Open Access This article is distributed under the terms of the Creative Commons Attribution 4.0 International License (http://creativecommons.org/licenses/by/4.0/), which permits unrestricted use, distribution, and reproduction in any medium, provided you give appropriate credit to the original author(s) and the source, provide a link to the Creative Commons license, and indicate if changes were made. The Creative Commons Public Domain Dedication waiver (http://creativecommons.org/publicdomain/zero/1.0/) applies to the data made available in this article, unless otherwise stated. 


\section{Introduction}

Historically, the rising incidence in obesity has been attributed to genetic background, changes in diet and the modern lifestyle, yet these factors fail to fully explain the rapid onset of the epidemic [1]. The commercial chemical registry instituted by the Toxic Substances Control Act currently consists of 84,000 chemicals [2]. At a minimum, 25,000 of these chemicals are actively used in commercial products today [3]. Exposures to these chemicals arise in the outdoor environment from industrial releases and the indoor environment from use of consumer goods. Widespread exposure to low doses of a number of these metabolism disrupting chemicals (MDCs), a class of endocrine disrupting chemicals (EDCs), has been linked to obesity due to their abilities to inappropriately activate fat-forming pathways and enhance weight gain through white fat accumulation [4].

The search for MDCs that act on adipose tissue has focused on identifying ligands for the nuclear receptor peroxisome proliferator activated receptor gamma (PPAR $\gamma$ ). PPAR $\gamma$ regulates white, brown, and brite (brown-in-white) adipogenesis, mature adipocyte maintenance, function and survival, and insulin sensitivity [5-7], as well as the balance of adipogenesis and osteogenesis $[8,9]$. PPAR $\gamma$ is a ligand-activated transcription factor that binds to the PPAR response element (PPRE, 5'-CAAAACAGGTCANAGGTCA-3') heterodimerized with the retinoid $\mathrm{x}$ receptors (RXR) to regulate gene transcription [10]. Activation of PPARY by exogenous ligands induces adipogenesis [11] and increases subcutaneous and abdominal adiposity [12, 13]. Additionally, PPAR $\gamma$ activation suppresses bone differentiation [14], resulting in bone marrow adiposity and reduced bone quality in mouse models $[15,16]$ and in humans $[17,18]$.

PPAR $\gamma$ ligands include structurally diverse endogenous and exogenous (natural and synthetic) ligands. Prostaglandins are known fatty acid-derived endogenous PPAR $\gamma$ ligands derived from the lipid membrane [19]. Exogenous ligands include naturally-occurring, therapeutic, and environmental chemicals. Natural products, such as foods and medicinal plants, containing PPARY activating constituents have been investigated for their potential therapeutic potential [20]. Drugs of the thiazolidinedione class (e.g. rosiglitazone, Avandia ${ }^{\circ}$ ) are highly potent PPARy agonists that upregulate PPARy's insulin sensitizing functions $[11,21]$. While thiazolidinediones activate PPAR $\gamma$ with potencies in the mid-nanomolar range, natural PPAR $\gamma$ ligands and endogenous compounds have micromolar potencies [11, 20, 22].

Environmental PPAR $\gamma$ ligands are a growing class of MDCs, including phthalates, organotins, brominated flame retardants, organophosphate flame retardants and polycyclic aromatic musks, which induce adipogenesis [23-29]. Environmental PPAR $\gamma$ ligands have potencies ranging from nanomolar (i.e., organotins) to micromolar (i.e., phthalates) [24, 25, 27]. In addition to inducing adipocyte differentiation in vitro, at least phthalates [30], organotins [31, 32], and organophosphate esters [33] also increase adiposity in vivo. Additionally, growing evidence suggests that reduced bone quality is an adverse health effect of environmental PPAR $\gamma$ ligands [34-36].

Detection of environmental PPARy ligands in human biological samples [37-41], confirms widespread exposure to these chemicals. People are exposed to a complex mixture of both environmental and therapeutic PPARY ligands, and components of these mixtures - full agonists, partial agonists and competitive antagonists - act cumulatively to activate PPAR $\gamma$ in a predictable manner [42]. Nuclear receptor-dependent bioassays can provide inexpensive and rapid assessments of the biological activities of ligand mixtures. Originally developed to measure the aryl hydrocarbon receptor activity of polyhalogenated aromatic hydrocarbons [43], chemical-activated gene luciferase (CALUX) bioassays have been adapted and validated for use as tools to assess exposure to environmental ligands, including aryl hydrocarbon receptor, estrogen receptor and PPARY ligands [44-50]. Here, we have developed a bioassay to quantify total PPAR $\gamma$ ligand activity in serum samples, using a rodent model and human serum samples from commercial sources. As PPARy forms an obligate, permissive heterodimer with RXR, and ligands for either receptor can lead to signaling [51], we paid careful attention to the role of both receptors.

\section{Materials and methods}

Materials Rosiglitazone (cat. \#71740) was from Cayman Chemical (Ann Arbor, MI). DMSO (in vitro, cat. \#AB03091) was from American Bioanalytical (Natick, MA). LG100268 (cat. \#SML0279), T0070907 (cat. \#T8703), DMSO (in vivo, cat. \#D1435), and carboxymethylcellulose (cat. \#C9481) were from Sigma-Aldrich (St. Louis, MO). HX 531 (cat. \#3912) was from Tocris Bioscience (Bristol, UK). All other reagents were from Thermo Fisher Scientific (Suwanee, GA), unless specified.

Animal studies Animal studies were approved by the Institutional Animal Care and Use Committee at Boston University and performed in an American Association for the Accreditation of Laboratory Animal Care accredited facility (Animal Welfare Assurance Number: A3316-01). Care was taken to minimize 
distress. Nine-week-old, female, C57BL/6 J mice (RRID:IMSR_JAX:000664, Jackson Laboratories, Bar Harbor, ME) were treated by oral gavage $(10 \mu \mathrm{L} / \mathrm{g})$ with vehicle (Vh, $1 \%$ carboxymethylcellulose, $0.1 \%$ DMSO), or rosiglitazone $(0.1,1,10,100 \mathrm{mg} / \mathrm{kg})$. One hour after gavage, mice were euthanized, and blood was collected via cardiac puncture. This time was chosen as it is the point of maximum serum concentrations following oral administration in humans [52, 53]. Serum was separated and frozen at $-80^{\circ} \mathrm{C}$.

Human sera samples Human $A B$ serum samples were purchased from commercial sources (Atlanta Biologicals, Flowery Branch, GA; Corning Cellgro, Tewksbury, MA; Gemini Bio-products, West Sacramento, CA; MP Biomedicals, Santa Ana, CA; Sigma-Aldrich, St. Louis, $\mathrm{MO})$. These sera were collected in the United States and were from men.

Reporter assays Cos-7 cells (RRID: CVCL_0224, CRL1651, ATCC, Manassas, VA) were maintained in Dulbecco's Modified Eagle's Medium (DMEM) (Corning Cellgro, Tewskbury, MA) with 5\% fetal bovine serum (FBS), amphotericin $\mathrm{B} /$ penicillin/streptomycin, and L-glutamine at $37^{\circ} \mathrm{C}$ and $5 \% \mathrm{CO}_{2}$ atmosphere. Cells were plated in 96well plates in antibiotic free media and transiently transfected with expression vectors, individually or in combination, containing human PPARG1 (provided by V.K. Chatterjee, U. Cambridge) [54], or human RXRA (plasmid 8882; Addgene, Cambridge, MA) [7] with PPRE $\times 3$-TK-luc (plasmid 1015; Addgene) [55] and CMV-eGFP (mammalian expression vector for expression of green fluorescent protein) (from our laboratory) reporter constructs. The sequence of the PPRE is $5^{\prime}$-GTCGACAGGGGACCAGGA CAAAGGTCACGTTCGGGAGTCGAC-3'). Transfected cultures were incubated overnight, and the media was replaced. Naïve wells were transfected with the reporter constructs alone and an empty pcDNA 3.1 plasmid (in proportion to the expression vectors) and left untreated. For chemical experiments, standard curve wells containing $100 \mu \mathrm{L}$ of medium were treated with $\mathrm{Vh}$ (DMSO, 0.5\%), rosiglitazone $\left(10^{-10}-2 \times 10^{-6} \mathrm{M}\right)$, or LG100268 $\left(10^{-10}-2\right.$ $\left.\mathrm{x} 10^{-6} \mathrm{M}\right)$. For serum experiments, standard curve wells containing $100 \mu \mathrm{L}$ of medium received $10 \mu \mathrm{L}$ charcoal-dextran stripped FBS and then were treated with Vh or standard curve chemicals. Experimental wells containing $100 \mu \mathrm{L}$ of medium were treated with $10 \mu \mathrm{L}$ of mouse serum in duplicate. Human serum was initially titrated at volumes ranging from $0.5-50 \mu \mathrm{L}$ to determine proper volume. In final human serum experiments, wells were treated with human serum in duplicate or quadruplicate $(10 \mu \mathrm{L})$. Referent (ref) wells containing $100 \mu \mathrm{L}$ of media received $10 \mu \mathrm{L}$ of stripped fetal bovine serum. In antagonist experiments, wells were treated with serum and then co-treated with Vh (DMSO:Ethanol, 50:50, 0.5\%), T0070907 $(1 \mu \mathrm{M})$ or HX $531(2 \mu \mathrm{M})$. After a $24 \mathrm{~h}$ incubation, cells were lysed using Steady-Luc Firefly HTS Reagent (Biotium, Freemont, CA). Luminescence (lum) and fluorescence (eGFP or flo) were measured using a Synergy2 multi-function plate reader (Biotek, Inc. Winooski, VT). eGFP values were analyzed to ensure that no treatment caused a significant decrease in fluorescence, as this is an indicator of toxicity. Data were normalized using a method to minimize intra- and inter-experimental variation [56], as follows:

$$
\text { Percent Positive Control Activity }=\frac{\operatorname{Exp}\left(\frac{\mathrm{lum}}{\text { flo }}\right)-\text { Naive }\left(\frac{\mathrm{lum}}{\text { flo }}\right)}{\text { Positive Control }\left(\frac{\text { lum }}{\text { flo }}\right)-\text { Naive }\left(\frac{\text { lum }}{\text { flo }}\right)}
$$

When subtraction of the Naïve (lum/flo) resulted in a negative number, the negative number was replaced with "0." Concentrations in the plateau of the dose response curves were used to generate the positive controls. Rosiglitazone-treated cultures $\left(10^{-7}-2 \times 10^{-6} \mathrm{M}\right)$ served as the positive control for PPAR $\gamma$-transfected cultures. LG100268-treated cultures $\left(10^{-6} \mathrm{M}\right)$ served as the positive control for RXR-transfected cultures. "PPRE transcriptional activity" is reported as the "\% Maximum Activity," relative to the positive control. To interpolate rosiglitazone concentrations in the mouse serum, the standard curve data were fit with the "log(agonist) vs. response (3 parameters)" function in conjunction with the "Interpolate unknowns from standard curve" function in Prism 6 (GraphPad Software, La Jolla, CA).

Immunoblotting Cos-7 cells were grown and maintained as described above. Whole cell lysates were prepared from Cos-7 cells and Cos-7 cells transfected with human PPARG1, human RXRA, mouse Pparg1 (plasmid 8886; Addgene), mouse Pparg2 (plasmid 8865; Addgene) [7], mouse Rxra, mouse Rxrb, or mouse Rxrg (provided by R. M. Evans, Salk Institute for Biological Studies) [57]. Cos-7 cells were washed twice with PBS, lysed in Cell Lysis Buffer (Cell Signaling Technology, Danvers, MA) and sonicated. The lysates were cleared by centrifugation, and the supernatants were used for protein expression analyses. Protein concentrations were determined by the Bradford method [58]. Total proteins $(15-80 \mu \mathrm{g})$ were resolved on $10 \%$ gels, transferred to a $0.2 \mu \mathrm{M}$ nitrocellulose membrane, and incubated with primary antibody (monoclonal rabbit anti-PPARy (cat. \#2443, Cell Signaling Technology) or monoclonal rabbit anti-RXR $\alpha$ (cat. \#3085, Cell Signaling Technology)). Immunoreactive bands were detected using HRP-conjugated antibodies (cat. \#7074, Cell Signaling Technology) followed by enhanced chemiluminescence. To assess protein loading, blots were re-probed with a $\beta$-actin-specific antibody (cat. \#A5441, Sigma-Aldrich). 
Statistical analyses Statistical analyses were performed with Prism 6 (GraphPad Software). For in vivo exposures, data are reported from individual mice $(n=4-$ 12). In reporter assays, serum samples were run in duplicate. Standard curves were fit with "log(agonist) vs. response (3 parameters)" function. Data are reported as means \pm standard errors. Student's t-tests and ANOVA (one and two factor) combined with Tukey-Kramer, Sidak's and Dunnett's multiple comparisons tests were used to determine statistical significance. All analyses were performed using $\alpha=$ 0.05 .

\section{Results}

First, we began by determining the essential elements needed to produce a robust reporter system. PPAR $\gamma$ binds to and activates transcription at PPREs as an obligate heterodimer with RXRs. To develop a biomarker of total serum PPARY ligand activity, we began by examining the expression of PPARY and RXRs in Cos-7 cells, the cell model for the reporter assay. Cos-7 cells endogenously express PPAR $\gamma$ and RXRs, the receptors necessary to support ligand-induced PPAR $\gamma$ activity (column 1 (left most), Fig. 1a-b). Expression of PPAR $\gamma$ could be augmented by transfection with an expression vector for human PPARG1 (column 2, Fig. 1a). The additional 30 amino acids for the PPAR 2 isoform (column 3 vs 4, Fig. 1a) retards the migration of the protein and comparison demonstrates that our transfection protocol specifically increases the expression of PPAR $\gamma 1$. While the specific compliment of RXRs could not be identified because the isoforms co-migrate, it is evident that Cos-7 cells express at least one isoform that co-migrates with human and mouse RXRs (Fig. 1b).

Next, we determined the efficacy of activation of a PPRE-driven reporter in human PPARG1-transfected Cos-7 cells. First, we tested if increasing the expression of PPAR $\gamma$ would improve the signal to noise ratio in the assay. Rosiglitazone, a PPAR $\gamma$-specific ligand [11], only significantly induced transcriptional activity in human PPARG1-transfected cells (Fig. 2). Second, we tested the rosiglitazone dose response for activation of PPAR $\gamma 1$. Prior to normalization by the positive control, the lum/flo values ranged from a minimum of $\approx 1$ to a maximum of $\approx 50$. As expected, rosiglitazone is a potent and efficacious ligand in this assay (Range: $10^{-10}-2$ x $\left.10^{-6} \mathrm{M}, \mathrm{EC}_{50}: 1.5 \times 10^{-8} \mathrm{M}\right)$ (Fig. 3a). We determined if the activity level could be increased further by co-transfecting with an $R X R A$ expression plasmid. Co-transfection of increasing amounts of human $R X R A$ expression plasmid with human PPARG1 did not increase induction of PPAR $\gamma$-dependent transcriptional activity by rosiglitazone (Fig. $3 \mathrm{~b}$ ).

The transcriptional activity of PPAR $\gamma$ can be activated by binding of a ligand to PPAR $\gamma$ itself or by binding of a ligand to its partner RXR in some cell types [51, 59]. Furthermore, RXR:RXR homodimers are known to activate transcription at PPREs [60]. Therefore, we examined the potential contribution of RXR activation to the PPRE transcriptional activity we were measuring. First, LG100268, an RXR-specific ligand [61], potently induced PPRE-dependent reporter activity when Cos-7 cells were transfected with human RXRA alone $\left(\mathrm{EC}_{50}=2.7 \times 10^{-9} \mathrm{M}\right)$ (Fig. 4a). To compare the efficacy of transcription at the PPRE
A PPAR $\gamma$

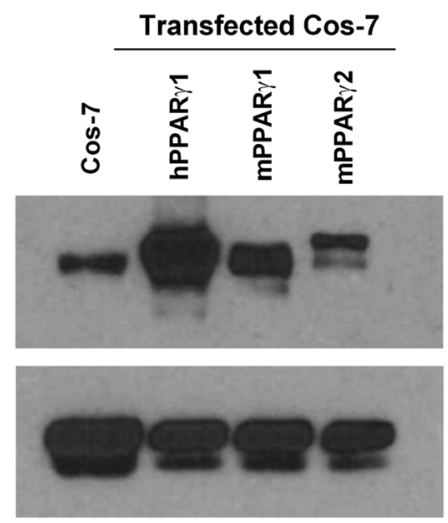

B RXR

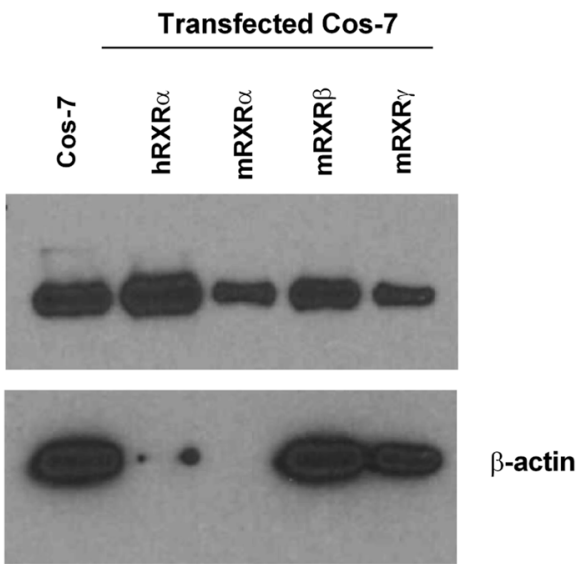

Fig. 1 Cos-7 cells endogenously express PPARy1 (A) and RXRs (B), proteins necessary for PPARy to activate transcription. Whole cell lysates were prepared from Cos-7 cells and Cos-7 cells transfected with (a) mouse Pparg1, mouse Pparg2, human PPARG1 expression vectors, or (b) human RXRA, mouse Rxra, mouse Rxrb, mouse Rxrg expression vectors. Lysates were analyzed for PPARY, RXRa, and $\beta$ actin expression by immunoblotting 


\begin{tabular}{|l|c|}
\hline Interaction & $\mathbf{p}=\mathbf{0 . 0 0 6}$ \\
\hline Transfection & $\mathbf{p}<\mathbf{0 . 0 0 0 1}$ \\
\hline Treatment & $\mathbf{p}<\mathbf{0 . 0 0 0 1}$ \\
\hline
\end{tabular}

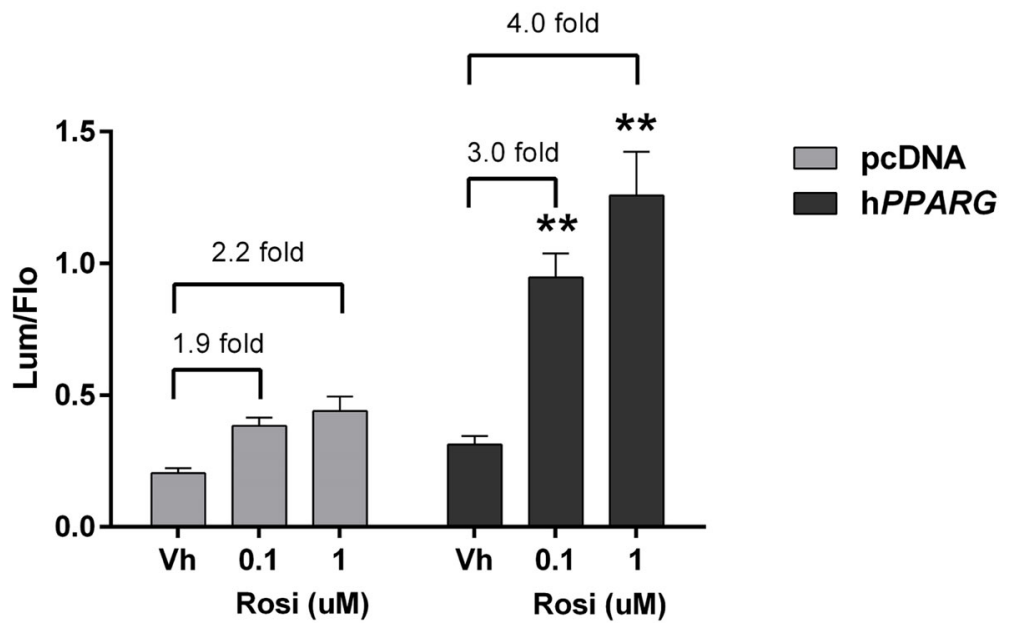

Fig. 2 Overexpression of PPARy significantly increases transcriptional response to rosiglitazone. Cos-7 cells were transfected with reporter plasmids (PPRE-luciferase reporter, CMV-GFP reporter) and empty pCDNA 3.1 or a mouse Pparg2 expression vector. Cells then were treated with Vh (0.5\% DMSO) or rosiglitazone (as indicated). Luminescence and fluorescence were measured after $24 \mathrm{~h}$. Data are reported as mean \pm standard error ( $N=7$ independent transfections). Statistical analyses indicated in the box are from a 2-Factor ANOVA. ** Significantly different from Vh $(p<$ 0.01, ANOVA, Dunnett's)

through RXR vs PPAR $\gamma$, we compared the lum/flo values. For PPAR $\gamma$, the maximal lum/flo is $\approx 50$, and for RXR, the maximal lum/flo is $\approx 5$. Therefore, PPAR $\gamma$ is approximately 10 -fold more efficacious at activating transcription at this PPRE. LG100268 did not significantly induce PPRE-dependent reporter activity when Cos-7 cells were transfected with human PPARG1 alone (Fig. 4b).
According to Schulman et al. (1998), co-exposures to PPAR $\gamma$ and RXR ligands induced synergistic activation of transcriptional activity at PPREs when both PPARG and RXR expression vectors were transfected into $3 \mathrm{~T} 3 \mathrm{~L} 1$ cells. We therefore assessed the potential interaction of PPAR $\gamma$ and RXR ligands in our assay. Contrary to expectation, treatment of human PPARG1 transfected Cos-7 with increasing concentrations of

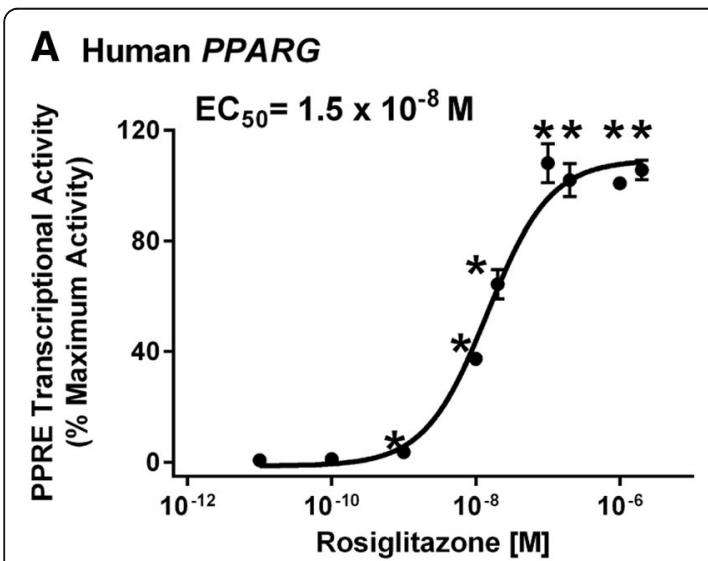

B Human PPARG + titrated Human RXRA

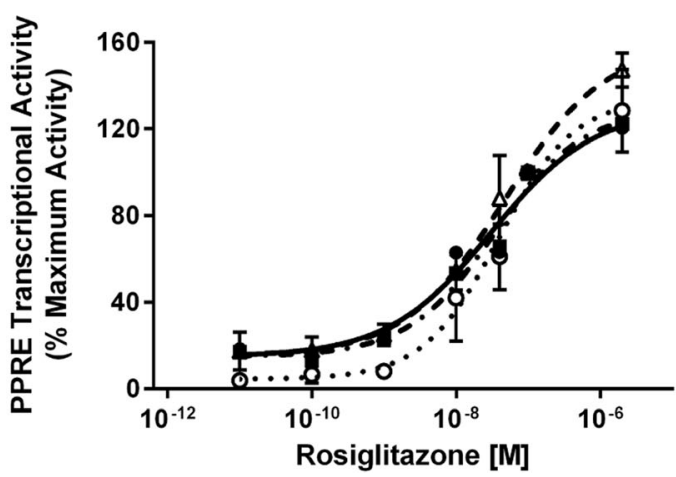

Human RXRA (ng /well)

... $0 \mathrm{ng}$

$-\cdot 7.5 \mathrm{ng}$

$--\Delta-\cdot 15 \mathrm{ng}$

$\longrightarrow 25 \mathrm{ng}$

Fig. 3 Overexpression of human PPARY1 alone is sufficient to support robust PPARY transcriptional activity. Cos-7 cells were transfected with reporter plasmids (PPRE-luciferase reporter, CMV-GFP reporter) and a human PPARG1 expression vector (a) or human PPARG1 and human RXRA expression vectors $(\mathbf{b})$. Cells then were treated with $\mathrm{Vh}\left(0.5 \% \mathrm{DMSO}\right.$, shown as $\left.10^{-11} \mathrm{M}\right)$ or rosiglitazone $\left(10^{-10}-2 \times 10^{-6} \mathrm{M}\right)$. Luminescence and fluorescence were measured after $24 \mathrm{~h}$. Data were calculated as described in the Methods. Dose response data are reported as mean \pm standard error ( $N=3-4$ independent transfections). Data were fit with a 3-parameter sigmoid equation. * Significantly different from $\mathrm{Vh}(p<0.05$, ANOVA, Dunnett's) 
A Human RXRA
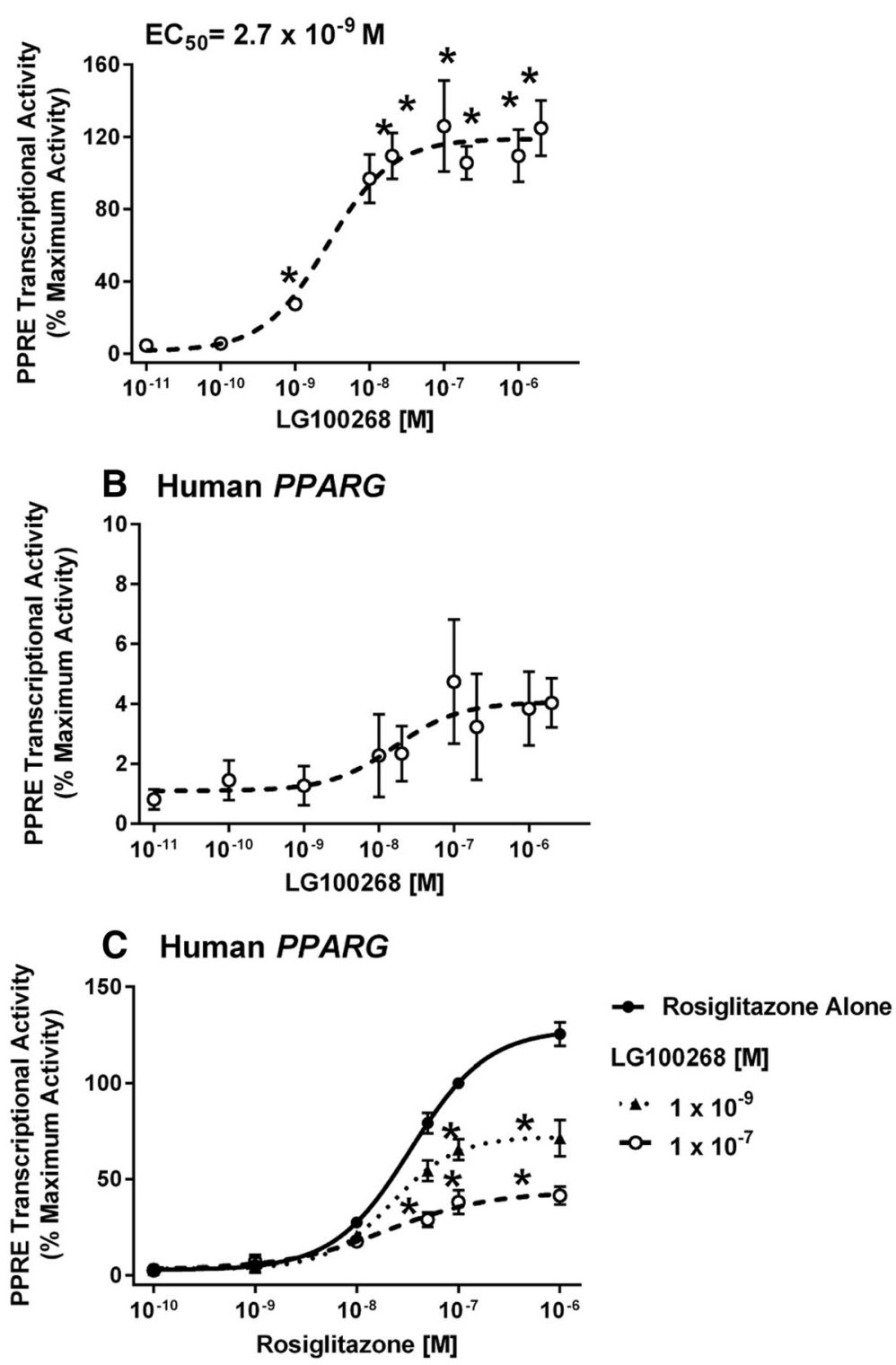

Fig. 4 RXR ligands do not significantly activate PPARY, but reduce rosiglitazone-induced, PPRE-dependent transcriptional activity. Cos-7 cells were transfected with reporter plasmids (PPRE-luciferase reporter, CMV-GFP reporter) and a human RXRA expression vector (a) or a human PPARG1 expression vector $(\mathbf{b}-\mathbf{c})$. Cells were treated with Vh $\left(0.5 \% \mathrm{DMSO}\right.$, reported as $\left.10^{-11} \mathrm{M}\right)$, rosiglitazone $\left(10^{-10}-2 \times 10^{-6} \mathrm{M}\right)$, and/or LG100268 $\left(10^{-10}-2 \times 10^{-6} \mathrm{M}\right)$. Luminescence and fluorescence were measured after $24 \mathrm{~h}$. Data were calculated as described in the Methods. Data are reported as mean \pm standard error $\left(N=4\right.$ independent transfections) ${ }^{*}$ Significantly different from $V h(p<0.05$, ANOVA, Dunnett's).

LG100268 decreased rosiglitazone-induced transcriptional activity (Fig. 4c).

Overall, rosiglitazone induced robust PPAR $\gamma$ dependent activity with the transfection of human PPARG1 alone. LG100268, an RXR specific ligand, did not by itself induce activity, as is optimal for a PPAR $\gamma$ transcriptional assay. However, LG100268 reduced the rosiglitazone-induced activity, suggesting that the assay may produce an underestimate of the
PPARY activity if RXR ligands are present in significant quantities in a mixture of ligands.

Second, we tested the efficacy of the assay in detecting a PPAR $\gamma$ ligand in serum. Increasing serum concentrations have been shown previously to reduce the apparent potency of ligands by reducing bioavailability [62]. We therefore generated a standard curve for rosiglitazone in the assay (transfected with $\mathrm{h} P P A R G 1$ ), adding $10 \mu \mathrm{L}$ charcoal-stripped FBS (Fig. 5). As expected, 

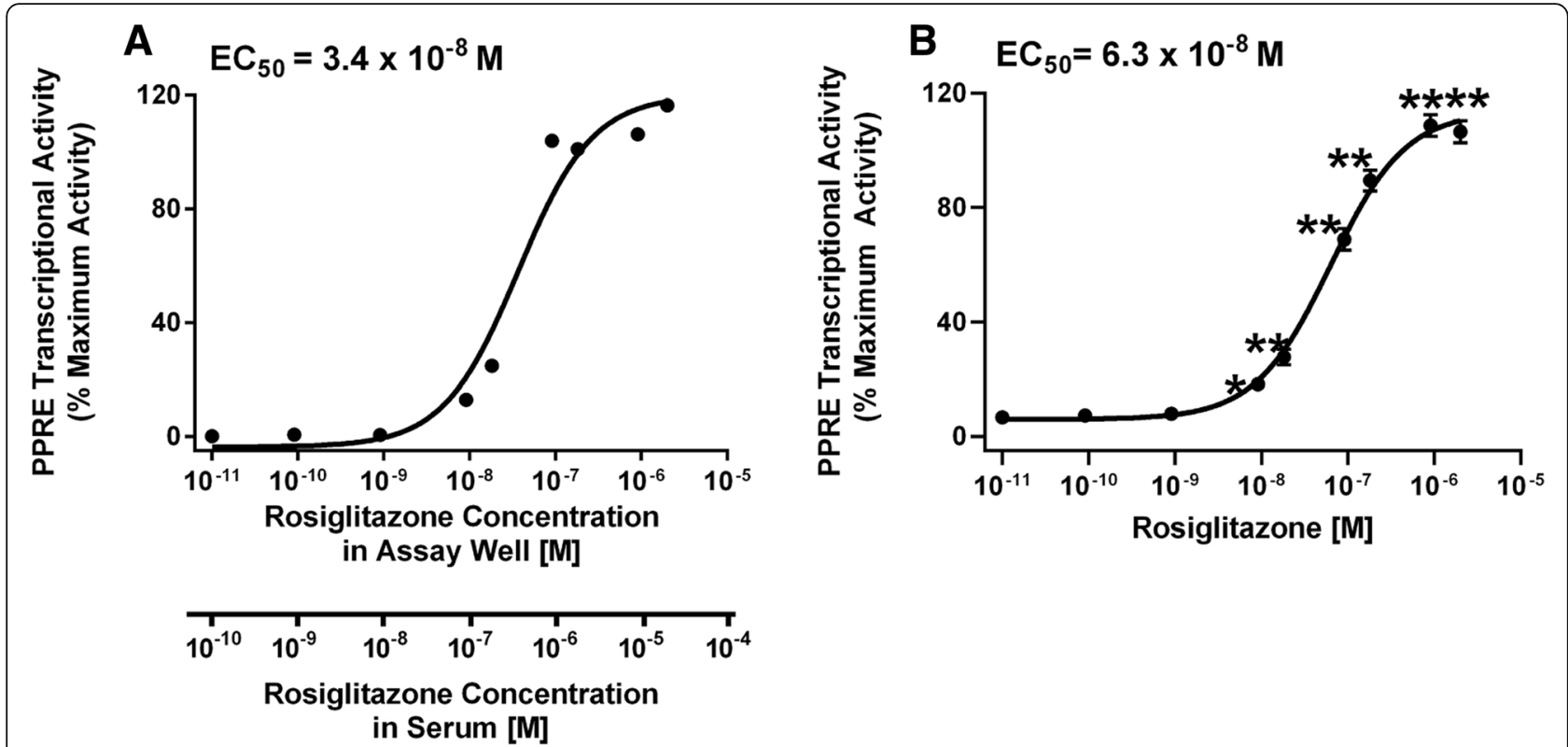

Fig. 5 Standard curve for rosiglitazone in the Serum PPARy Activity Assay with added serum. Cos-7 cells were transfected with reporter plasmids (PPRE-luciferase reporter, CMV-GFP reporter) and a human PPARG1 expression vector. Charcoal stripped serum (10 $\mu$ I) was added to each well and then the wells were treated with Vh $\left(0.5 \%\right.$ DMSO, shown as $\left.10^{-11} \mathrm{M}\right)$ or rosiglitazone $\left(10^{-10}-2 \times 10^{-6} \mathrm{M}\right)$, in duplicate. Luminescence and fluorescence were measured after $24 \mathrm{~h}$. Data were calculated as described in the Methods. Data were fit with a 3parameter sigmoid equation. (a) Standard curve used to calculate mouse serum rosiglitazone concentrations. The upper $X$ axis indicates the concentrations of rosiglitazone in the total volume in the assay well $\left(10^{-10}-2 \times 10^{-6} \mathrm{M}\right)$. The lower $\mathrm{X}$ axis indicates the concentrations of rosiglitazone in the volume of excess serum added to the well $\left(10^{-9}-2 \times 10^{-5} \mathrm{M}\right)$. (b) Compilation of standard curves performed between 2016 and 2019. Data are reported as mean \pm standard error ( $N=29$ independent transfections). Significantly different from Vh (* $p<0.05,{ }^{* *} p<0.01$, ANOVA, Dunnett's)

rosiglitazone has a slightly higher $\mathrm{EC}_{50}$ of $6.3 \times 10^{-8}$ $\mathrm{M}$ compared to conditions without excess serum: $\mathrm{EC}_{50}=1.5 \times 10^{-8} \mathrm{M}$ (Fig. 3a). Since our goal is to measure PPARY agonist activity in serum, we therefore used the standard curve in Fig. 5 for the analyses. We define the limit of detection (LOD) here as the lowest concentration yielding PPRE transcriptional activity that is significantly different from Vh: $9 \times 10^{-}$ ${ }^{9} \mathrm{M}$ (Fig. 5b). The true LOD may be lower. As we will test the activity of a small amount of added serum, it is important to adjust concentrations for dilution. For $10 \mu \mathrm{L}$ of serum added to $100 \mu \mathrm{L}$ already in the well, the final concentration will be $1 / 11$ (9\%) of that in the serum. The LOD for rosiglitazone in added serum thus is approximately $10^{-7} \mathrm{M}$ or $100 \mathrm{nM}$ (see lower $\mathrm{X}$ axis, Fig. 5a).

Serum likely contains endogenous PPAR $\gamma$ and RXR ligands that could potentially swamp or mask the activity of exogenous compounds. We therefore generated serum samples from C57BL/6 mice one hour after exposure via oral gavage to $\mathrm{Vh}$ or four doses of rosiglitazone. The serum was applied directly to Cos-7 cells transiently transfected with human PPA
RG1. Serum from Vh-treated mice had a significantly greater PPRE transcriptional activity than stripped FBS (5.2 \pm 0.7 vs $0.1 \pm 0.1 \%$ Maximum Activity, respe ctively; $p<0.006$, Student's t-test), thus there is likely endogenous or food-derived agonists present in mouse serum. Serum from rosiglitazone-treated mice activated PPAR $\gamma$-dependent transcription in a dosedependent manner. When analyzed using a Student's $\mathrm{t}$ test, the lowest dose of rosiglitazone $(0.1 \mathrm{mg} / \mathrm{kg})$ also induced a significant increase in PPRE transcriptional activity relative to the background activity measured in Vh-treated mice $(p<0.02)$. Figure 6a shows the PPAR $\gamma$ activity associated with various doses; Fig. 5 provides the rosiglitazone concentrations associated with various levels of PPARy activity. Taking into account volume dilution from adding serum to the assay, we estimate that the $0.1 \mathrm{mg} / \mathrm{kg}$ and $1 \mathrm{mg} / \mathrm{kg}$ doses resulted in mouse serum concentration of 55 $\mathrm{nM}(20 \mathrm{ng} / \mathrm{ml})$ and $1.6 \mu \mathrm{M}(580 \mathrm{ng} / \mathrm{ml})$, respectively. Analysis of serum from mice treated with Vh or rosiglitazone on three separate days showed that the measured PPRE transcriptional activity was highly reproducible (Fig. 6b). The specificity of the assay for 


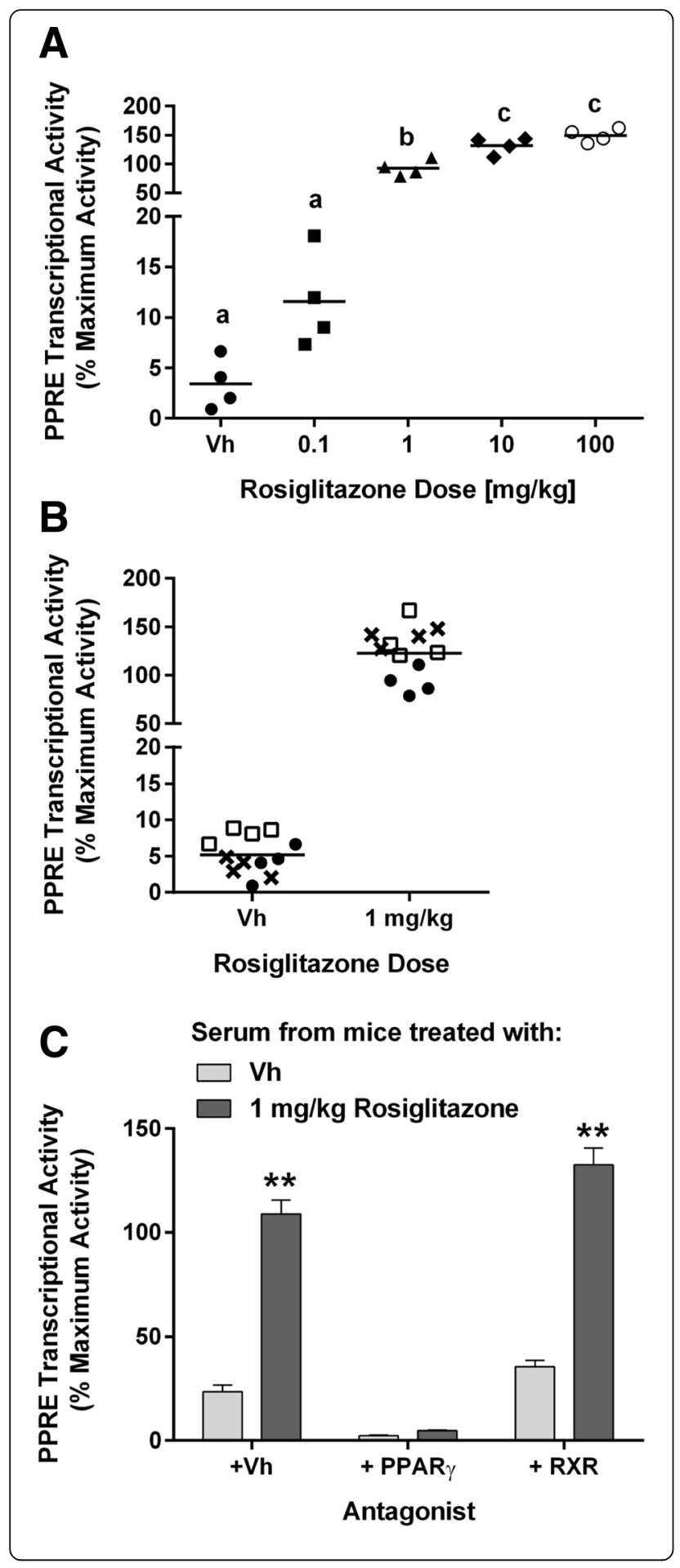

Fig. 6 Serum PPARY Activity can be detected in whole serum from rosiglitazone-treated mice in a dose-dependent manner. Sera were generated from nine-week-old, female, C57BL/6 J mice were treated by oral gavage with $\mathrm{Vh}$ ( $1 \%$ carboxymethylcellulose, $0.1 \% \mathrm{DMSO}$ ) or rosiglitazone $(0.1,1,10,100 \mathrm{mg} / \mathrm{kg})$ and euthanized after $1 \mathrm{~h}$. Sera were analyzed in Cos-7 cells transfected with reporter plasmids (PPRE-luciferase reporter, CMV-GFP reporter) and human PPARG1. Experimental wells were treated with $10 \mu \mathrm{L}$ mouse serum, in duplicate. Luminescence and fluorescence were measured after $24 \mathrm{~h}$. Data were calculated as described in the Methods and were calculated relative to the standard curve shown in Fig. 5. (a) Dose response of serum PPRE transcriptional activity. All mice were treated on the same day. (b) Reproducibility assessment. Mice were treated on three different days, with independently prepared dose solutions. Mice from each experiment are indicated by different symbols. For A and B, individual data are plotted with the mean indicated by a line. Different letters indicate group means that differed significantly, while groups with the same letter did not differ significantly ( $p<0.05$, ANOVA, Tukey). (c) To test for receptor specificity, wells treated with serum from mice that were exposed to Vh or to $1 \mathrm{mg} / \mathrm{kg}$ rosiglitazone were co-treated with Vh (0.5\%, 50:50, DMSO:Ethanol), PPARY antagonist (T0070907, $1 \mu \mathrm{M}$ ) or RXR antagonist $(\mathrm{HX} 531,2 \mu \mathrm{M})$. For $\mathrm{C}$, data are presented as means \pm standard error from all mice in the treatment group. Significantly different from Vh $\left(^{* *} p<0.01,2\right.$-Factor ANOVA, Sidak's)

PPAR $\gamma$-mediated PPRE transcriptional activity is shown by the complete abrogation of the serum-induced activity by T0070907, a PPAR $\gamma$ antagonist, but not HX 531, an RXR antagonist (Fig. 6c).

Overall, the results demonstrated that PPAR $\gamma$ agonist activity can be detected in whole serum, and that the activity is dose-dependent. Therefore, in the Serum PPAR $\gamma$ Activity Assay (SPAA), we proceeded with transfecting Cos-7 cells with human PPARG1, the PPRE reporter, and the control reporter (CMV-eGFP).

Third, in order to determine the sensitivity of our bioassay to detect potentially low levels of PPAR $\gamma$ ligands in normal human serum, we examined the activation of PPARy by commercial human serum samples. We began by titrating increasing amounts of human serum in the SPAA to determine the lowest volume that would provide a maximal signal. Increasing the volume of serum in the assay increased PPRE transcriptional activity (Fig. 7a), which was well fit by a sigmoid curve (Fig. 7b). We choose to use $10 \mu \mathrm{L}$ of human serum because it was the lowest volume that induced a maximal PPAR $\gamma$ transcriptional activity across the human serum samples.

Comparison of the serum PPAR $\gamma$ agonist activity in five human serum samples purchased from different commercial sources showed that there is a range of detectable activity in normal human serum, which is dependent upon the volume of serum applied (Fig. 8a). The PPRE transcriptional activity induced by each sample at $10 \mu \mathrm{L}$ was significantly different from the 


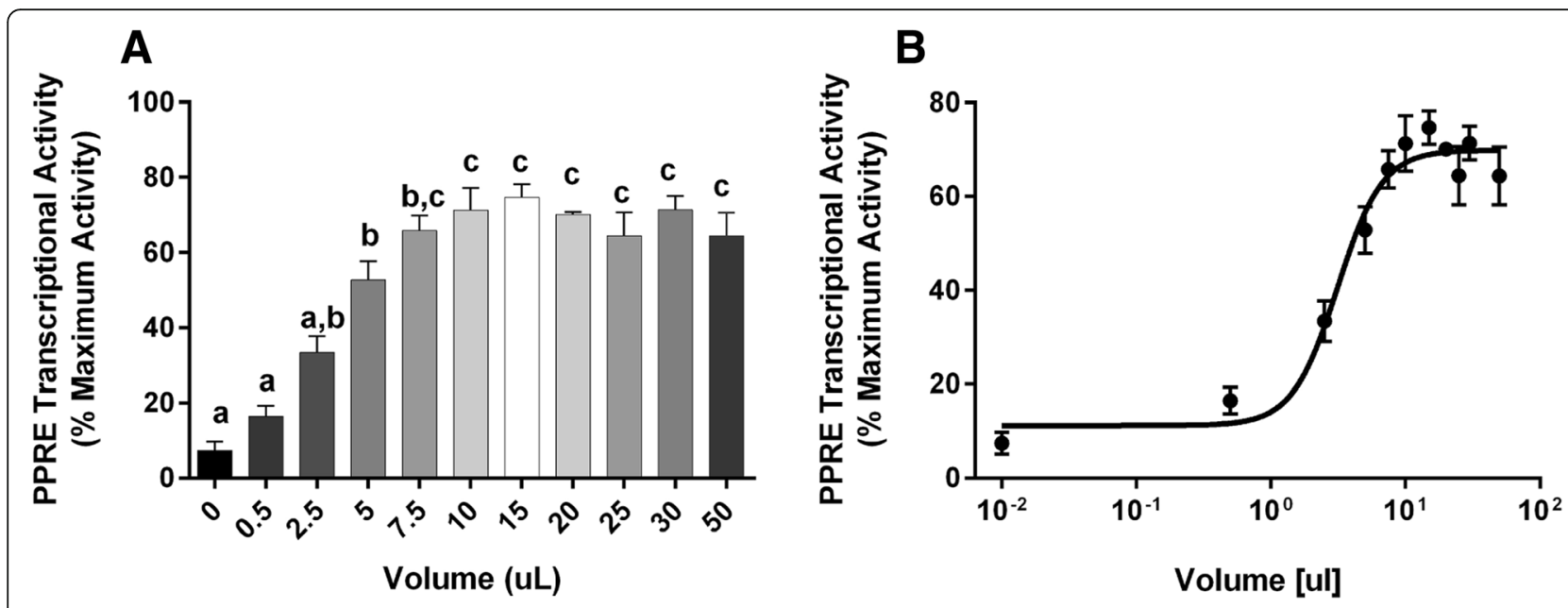

Fig. 7 Determination of optimal serum volume in the SPAA. Cos-7 cells were transfected, and control wells were treated as described in Fig. 5. Experimental wells were treated with $0.5-50 \mu \mathrm{L}$ of serum. Luminescence and fluorescence were measured after $24 \mathrm{~h}$. Data were calculated as described in the Methods. (a) PPRE transcriptional activity measured in different volumes of serum (Gemini). Different letters indicate group means that differed significantly, while groups with the same letter did not differ significantly $(p<0.05$, ANOVA, Tukey). (b) Dose response fit of PPRE transcriptional activity measured in different volumes of serum. Dose response data were fit with a 3-parameter sigmoid equation. Data are reported as mean \pm standard error ( $N=3$ independent transfections)

activity induced in the reference wells to which charcoal stripped FBS was applied (Fig. 8b). There were differences in the absolute values of PPRE transcriptional activity determined on different days (using distinct plasmid preps and cell passages) (Fig. 8c); however, the data were highly correlated even when samples were run years apart. The PPRE activity in the commercial human serum sample was reduced to the level of the reference samples (charcoal-stripped FBS) by a PPARY antagonist, demonstrating the specificity of the assay (Fig. 8d). These data demonstrate the bioassay's ability to detect a range of activities from unknown exogenous and endogenous ligands in small volumes of serum.

\section{Discussion}

The growing concern with environmental chemical-mediated disruption of metabolism and obesity warrants improved methods to quantify exposure to environmental MDCs [4]. The traditional methods of assessing exposure to a single chemical fail to capture real world scenarios in which populations are exposed to multiple chemicals at a time, and these mixtures of chemicals may cause inappropriate activation of biological pathways. PPARY plays a critical role in regulating lipid homeostasis, insulin sensitivity and bone homeostasis through the induction of target genes, thus making it a target for endocrine disruption by environmental MDCs [63].

The Serum PPAR $\gamma$ Activity Assay (SPAA) was developed to measure the total PPAR $\gamma$ activity of serum samples. SPAA uses Cos-7 cells transfected with PPAR $\gamma$, a PPRE-driven reporter, and a constitutively active control reporter. We selected human PPAR 1 as the most appropriate ligand target because, compared to PPAR 2 , PPAR 1 is more broadly expressed in tissues such as adipose, liver, kidney, muscle tissue, heart, and spleen [64, 65]. Table 1 provides information on all of the reagents needed to perform the assay. While only serum was tested in these analyses, the assay is expected to be compatible with plasma, as well. However, results from serum and plasma are not comparable, as they contain different concentrations of proteins that could affect the bioavailability of ligands. Figure 9 presents the assay protocol. To maximize reproducibility and for the most accurate comparison across samples, the same plasmid preparation, positive control solution and serum standard should be used to analyze samples. Additionally, Cos-7 cells at similar passage numbers should be used. Both positive controls and serum standards should be run on every plate. The serum standard could be used as an additional normalization factor for samples run with distinct plasmid preparations. Last, the receptor-specificity of the serum-induced activity can be determined by using antagonists to PPAR $\gamma$ and RXR as indicated in the protocol.

Peak serum concentrations of rosiglitazone in humans occur one hour after oral administration [52, 53]. The maximum serum concentration of rosiglitazone in humans after receiving the lowest therapeutic dose ( $1 \mathrm{mg}$; approximately $0.1 \mathrm{mg} / \mathrm{kg}$ ) is $76 \mathrm{ng} / \mathrm{mL}$ [66]; this is approximately equivalent to $200 \mathrm{nM}$ in 


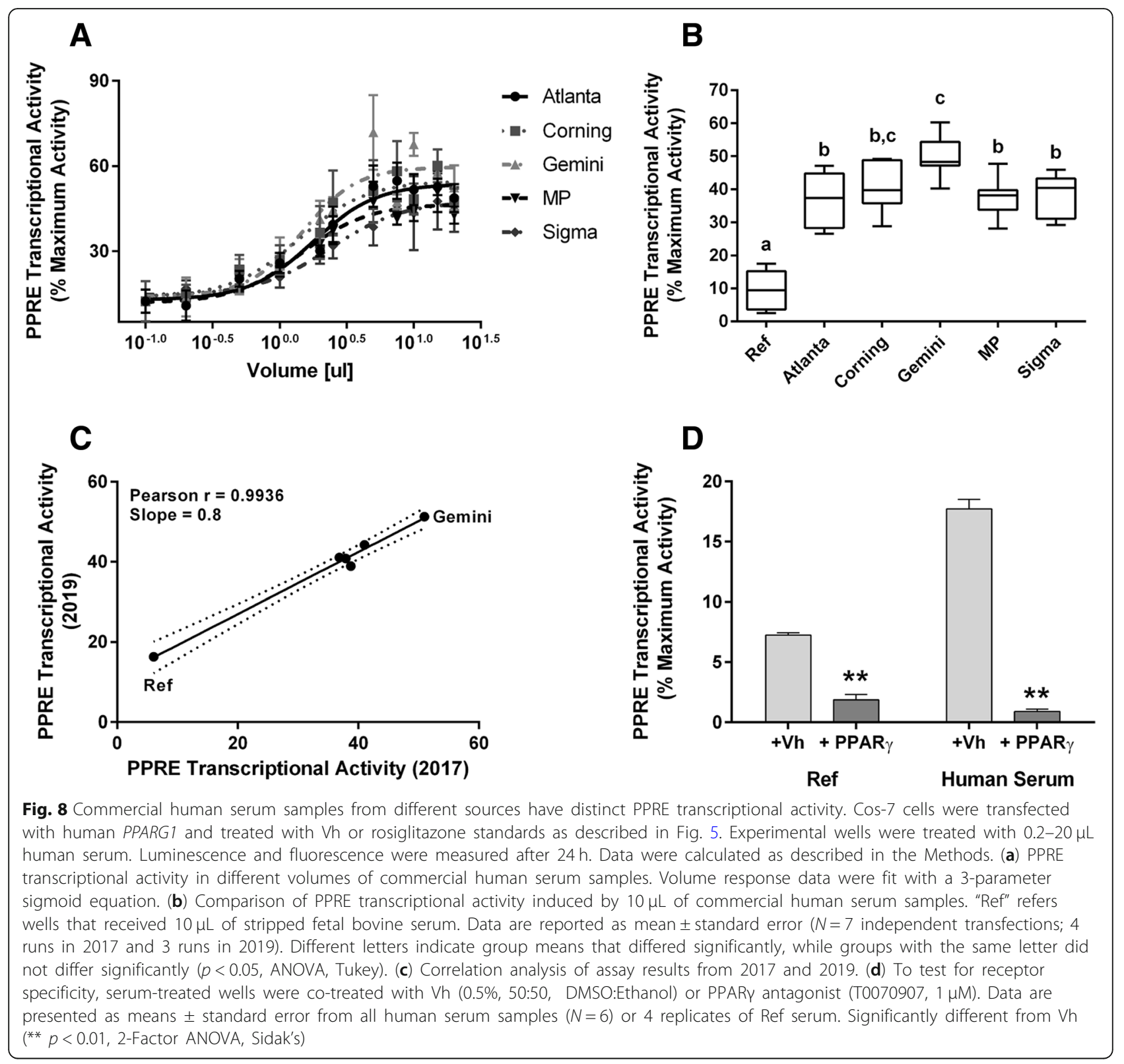

serum or $20 \mathrm{nM}$ the assay well. At $1 \mathrm{~h}$ following gavage, serum from mice dosed with $0.1 \mathrm{mg} / \mathrm{kg}$ rosiglitazone induced PPRE transcriptional activity equivalent to $55 \mathrm{nM}(20 \mathrm{ng} / \mathrm{mL})$ rosiglitazone. The activity serum of mice treated with $0.1 \mathrm{mg} / \mathrm{kg}$ rosiglitazone was significantly greater than the activity measured in serum from Vh-treated mice, and the "endogenous" activity measured in the serum of Vh-treated mice was significantly greater than the activity in wells treated with stripped serum. SPAA thus is sensitive enough to detect PPARY ligand activity in serum at levels below that induced by the lowest therapeutic dose in humans.
In vitro assays used alone or in combination with instrumental analyses, such as chromatography with mass spectrometry, increasingly have been used to detect and assess metabolic and endocrine disrupting chemicals. Previously developed CALUX bioassays have been used to measure PPAR $\gamma$ activity in food extracts, animal tissue, dust, and water samples [67-70]; these assays are available for purchase. However, RXR forms a permissive heterodimer with PPAR $\gamma$ and a ligand for either receptor can activate PPAR $\gamma$-dependent transcriptional activity. Thus, RXR ligands, either endogenous (9-cis retinoic acid) or synthetic (rexinoids LG100268), can promote the transcription of PPARy target genes [51, 
Table 1 Reagents to perform the Serum PPARY Activity Assay

$$
\text { Reagents and Supplies }
$$

\section{Cos-7 cells (RRID:CVCL_0224, CRL-1651, ATCC)}

Maintenance media: Dulbecco's Modified Eagle's Medium (DMEM) (Corning Cellgro, Tewskbury, MA) with 5\% fetal bovine serum (FBS), amphotericin B/penicillin/streptomycin, and L-glutamine

96-Well White-sided Clear Bottom Plates (cat. \#: 07-200-566; Corning)

Plasmids:

human PPARG1 [54] or mouse Pparg1 (plasmid 8886; Addgene) PPRE-3x-Tk (plasmid 1015; Addgene)

pcDNA (plasmid 20011; Addgene)

CMV-eGFP (plasmid 11153; Addgene) ${ }^{b}$

Lipofectamine 2000 Transfection Reagent (cat. \#: 11668019; Thermo Fisher Scientific)

Opti-MEM Reduced Serum Media (cat. \#: 31985062; Thermo Fisher Scientific)

Charcoal/Dextran stripped FBS (cat. \#: F6765, Sigma)

Rosiglitazone (cat. \#: 71740; Cayman Chemical)

T0070907 (cat. \#: T8703; Sigma)

Vehicle solvent mix (50\% Ethanol (cat. \#: 04-355-453, Fisher Scientific):

50\% Dimethyl sulfoxide (cat. \#: AB03091; American Bioanalytical))

Commercial Human Serum Standard (cat. \#: 100-512, Gemini

Bio-Products)

Steady-Luc Firefly HTS Assay (cat. \#: 30028-L3; Biotium)

${ }^{a}$ We used human PPARY1 provided by V.K. Chatterjee

${ }^{\mathrm{b}}$ We used CMV-eGFP made in house

59]. In the PPAR $\gamma$ CALUX validation study, it was speculated that some of the induced activity could be a result of the activation of endogenous RXR. Yet, the researchers did not directly consider the role of RXR [48, 67]. In our bioassay, an RXR ligand does not induce significant transcription of the PPRE-driven reporter when only PPARG1 is transfected, a desirable feature of a PPAR $\gamma$ assay. It has been suggested that the combination of a PPARY ligand and an RXR ligand can synergistically activate PPAR $\gamma$-dependent transcription [51]. However, studies indicate that the permissive activity of the PPARY - RXR heterodimer is largely dependent on cell type [71]. In our bioassay, increasing concentrations of a potent, synthetic RXR ligand reduced rosiglitazone-induced PPAR $\gamma$ transcriptional activity. However, endogenous, and natural RXR ligands (e.g. 9-cis-retinoic acid, phytanic acid, docosahexaenoic acid) have significantly lower potencies than LG100268 [72]. Thus, if RXR ligands are present in a serum sample, the activity of the PPAR $\gamma$ ligands may be underestimated; although the concentrations would have to be quite high for there to be a significant effect.

SPAA provides a measure of the combined activity of mixtures of PPAR $\gamma$ ligands in whole serum: a biological measure of exposure to mixtures containing full agonists, partial agonists and competitive antagonists. Generalized concentration addition (GCA) has been shown to accurately model the activity of mixtures of PPARy ligands [42]. One possible use of
SPAA is as a measure of exposure (biomarker of exposure) for epidemiology studies, particularly if combined with effect directed analysis to determine which mixture components are responsible for total activity [73, 74]. Alternatively, a combination of targeted instrumental analysis and GCA would yield an estimate of explained PPAR $\gamma$ activity that could be compared with total measured activity. For applications in epidemiological assessments, SPAA requires a very small volume of serum for testing ( 3 by $10 \mu \mathrm{L}$ samples). Furthermore, this assay is cost effective and does not require any specialized equipment; most of the research materials can be found in a standard cell culture laboratory.

Importantly, SPAA is a first step in connecting PPAR $\gamma$ ligand exposure to adverse metabolic and bone health effects. Analysis of the distribution of serum-induced PPRE transcriptional activities could reveal the potential for exposure to environmental ligands. A normal distribution would suggest that the activity is largely derived from endogenous ligands, while a right-skewed distribution could indicate an environmental exposure or a therapeutic exposure. Identification of the chemical source of the activation would then be needed. White adipogenic, brite/brown adipogenic, insulin sensitizing and bone suppressing activities of PPAR $\gamma$ are regulated separately through differential post-translational modifications [21] and co-regulator recruitment [75], with ligands having distinct abilities to activate these PPAR $\gamma$ functions. Thus, the glitazone class of T2DM therapeutics (e.g., rosiglitazone and pioglitazone) activates PPAR $\gamma$, stimulates brite adipocyte differentiation and increases insulin sensitivity [21], but improvement in metabolic health comes with significant side effects, including fat accumulation, hemodilution, cardiac hypertrophy and bone loss. Not surprisingly, these adverse effects also are mediated by PPAR $\gamma$. We have shown that environmental ligands cause PPAR $\gamma$ to act in a biologically distinct manner. Because these ligands cannot trigger PPARy to recruit the same coregulators they favor PPARy's ability to generate white adipocytes and to suppress bone formation [76, 77].

\section{Conclusions}

A goal of our study was to develop an assay that can be reproduced in any cell culture laboratory. All the cells and reagents to perform this assay are publicly available, and the protocol is straightforward and uses common laboratory equipment. The results from this study lay the foundation for future work on the use of biomarkers of PPAR $\gamma$ ligand exposure that incorporate mixture effects. Our simple and cost-effective 
Day 1

\begin{tabular}{|c|c|}
\hline \multicolumn{2}{|c|}{$\begin{array}{l}\text { Plate } 10,000 \text { Cos } 7 \text { cells }(100 \mu L) \text { in a } 96-\text { well clear } \\
\text { bottom plate in antibiotic-free media }\end{array}$} \\
\hline Day 2 & Incubate 24 hours \\
\hline \multicolumn{2}{|c|}{$\begin{array}{c}\text { Prepare solution of plasmid mixtures. } \\
\text { Mix } 0.025 \mu \mathrm{g} / \text { well of each plasmid into Opti-MEM for a } \\
\text { total volume of } 12.5 \mu \mathrm{L} / \text { well } \\
\text { Naive: } \\
\text { PPRE-x3-TK-luc, CMV-GFP, and pcDNA } \\
\text { Experimental: } \\
\text { PPRE-x3-TK-luc, CMV-GFP, and hPPARG1 }\end{array}$} \\
\hline & Warm solutions 20 mins \\
\hline \multicolumn{2}{|c|}{$\begin{array}{l}\text { Mix } 0.5 \mu \mathrm{L} / \text { well of Lipofectamine } 2000 \text { into } 12.5 \mu \mathrm{L} / \text { well } \\
\text { reduced serum medium }\end{array}$} \\
\hline & \\
\hline \multicolumn{2}{|c|}{$\begin{array}{l}\text { Combine the plasmid and Lipofectamine solutions and } \\
\text { add } 25 \mu \mathrm{L} / \text { well }\end{array}$} \\
\hline Day 3 & Incubate $12-16$ hours \\
\hline \multicolumn{2}{|c|}{ Replace media with $100 \mu \mathrm{L}$ of antibiotic-free media } \\
\hline \multicolumn{2}{|c|}{ 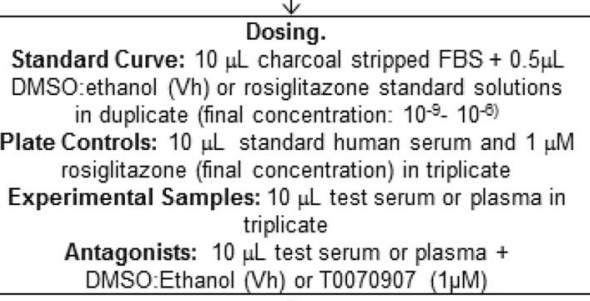 } \\
\hline Day 4 & Incubate 24 hours \\
\hline \multicolumn{2}{|c|}{$\begin{array}{l}\text { Remove } 50 \mu \mathrm{L} \text { media and replace with } 50 \mu \mathrm{L} \text { of Steady- } \\
\text { Luc Firefly HTS Reagent }\end{array}$} \\
\hline & $\begin{array}{l}\text { Incubate on orbital shaker } \\
\text { for } 5 \text { mins }\end{array}$ \\
\hline \multicolumn{2}{|c|}{$\begin{array}{c}\text { Analyze for fluorescence and luminescence activity on } \\
\text { microplate reader }\end{array}$} \\
\hline & \\
\hline $\begin{array}{l}\text { Calculate } \\
\% \text { Maxim } \\
\text { (Exp. We } \\
\text { lum/flo - }\end{array}$ & $\begin{array}{l}\text { iglitazone control: } \\
\text { lum/flo) } /(\text { Std. Well } \\
00\end{array}$ \\
\hline
\end{tabular}

Transfection plate setup: All plates

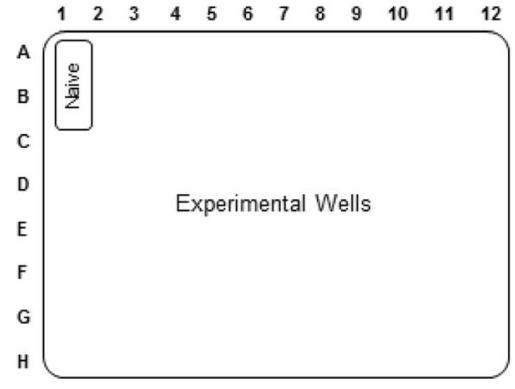

Dosing plate setup:

Standard curve plate

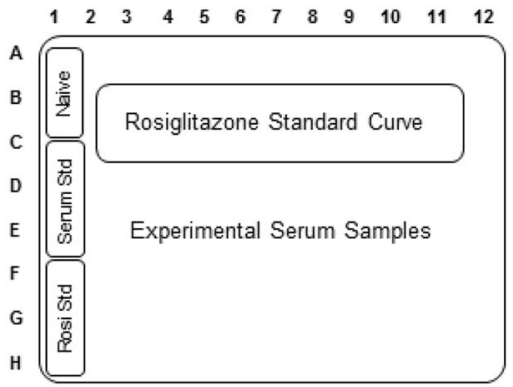

Dosing plate setup:

All other plates

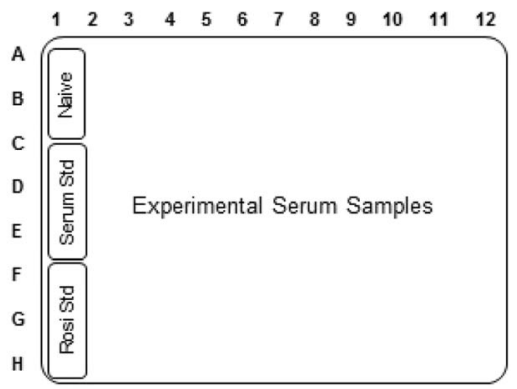

Fig. 9 Flowchart and sample plate designs for performing the Serum PPARy Activity Assay

assay is both sensitive and specific to PPAR $\gamma$ ligands, including those present in whole serum samples. While this study did not characterize the components in serum that were driving activity, future work will investigate environmental chemical contributors to activity in a set of serum samples with well-documented exposure histories.

\section{Abbreviations}

EDCs: Endocrine disrupting compounds; MDCs: Metabolism disrupting compounds; PPARY: Peroxisome proliferator activated receptor-gamma; PPRE: PPAR response element; RXR: Retinoid $x$ receptor

\section{Acknowledgements}

Not applicable.

\section{Funding}

This work was supported by a Superfund Research Program grant P42ES007381 (J.J.S.), an EPA STAR award FP91779801 (L.E.), and NIH grants R01ES027813 and R01 ES028800 (T.F.W.)

\section{Availability of data and materials}

The datasets used and/or analyzed during the current study are available from the corresponding author on reasonable request.

Authors' contributions

LE performed the in vivo experiments and the majority of the in vitro experiments, analyzed data and was the primary contributor in writing the 
manuscript. JW performed the initial experiments testing plasmid conditions. TFW participated in experimental design and was a major contributor in writing the manuscript. JJS participated in experimental design, participated in the in vivo experiments, analyzed data and was a major contributor in writing the manuscript. All authors read and approved the final manuscript.

\section{Ethics approval and consent to participate}

Animal studies were reviewed and approved by the Institutional Animal Care and Use Committee at Boston University and performed in an American Association for the Accreditation of Laboratory Animal Care accredited facility (Animal Welfare Assurance Number: A3316-01). All animals were treated humanely and with regard for alleviation of suffering.

\section{Consent for publication}

Not applicable.

\section{Competing interests}

The authors declare that they have no competing interests.

\section{Publisher's Note}

Springer Nature remains neutral with regard to jurisdictional claims in published maps and institutional affiliations.

\section{Received: 7 January 2019 Accepted: 24 April 2019}

Published online: 09 May 2019

\section{References}

1. Thayer KA, Heindel JJ, Bucher JR, Gallo MA. Role of environmental chemicals in diabetes and obesity: a national toxicology program workshop review. Environ Health Perspect. 2012;120(6):779-89.

2. Pool R, Rusch $E$, Institute of Medicine (U.S.). roundtable on environmental health sciences research and medicine: identifying and reducing environmental health risks of chemicals in our society : workshop summary. Washington, D.C.: the National Academies Press; 2014.

3. Myth versus fact about chemicals in commerce. [http://www.socma.com/ advocacy/issues/chemical-risk-management/myth-versus-fact-aboutchemicals-in-commerce]

4. Heindel JJ, Blumberg B, Cave M, Machtinger R, Mantovani A, Mendez MA, Nadal A, Palanza P, Panzica G, Sargis R et al: Metabolism disrupting chemicals and metabolic disorders. Reproductive toxicology (Elmsford, NY 2017, 68:3-33.

5. Anghel SI, Bedu E, Vivier CD, Descombes P, Desvergne B, Wahli W. Adipose tissue integrity as a prerequisite for systemic energy balance: a critical role for peroxisome proliferator-activated receptor gamma. J Biol Chem. 2007; 282(41):29946-57.

6. Imai T, Takakuwa R, Marchand S, Dentz E, Bornert JM, Messaddeq N, Wendling $\mathrm{O}$, Mark M, Desvergne B, Wahli W, et al. Peroxisome proliferatoractivated receptor gamma is required in mature white and brown adipocytes for their survival in the mouse. Proc Natl Acad Sci U S A. 2004; 101(13):4543-7.

7. Tontonoz P, Hu E, Graves RA, Budavari Al, Spiegelman BM. mPPARy2: tissuespecific regulator of an adipocyte enhancer. Genes Dev. 1994;8:1224-34.

8. Akune T, Ohba S, Kamekura S, Yamaguchi M, Chung UI, Kubota N, Terauchi Y, Harada Y, Azuma Y, Nakamura K, et al. PPARgamma insufficiency enhances osteogenesis through osteoblast formation from bone marrow progenitors. J Clin Invest. 2004;113(6):846-55.

9. Ducy P, Zhang R, Geoffroy V, Ridall AL, Karsenty G. Osf2/Cbfa1: a transcriptional activator of osteoblast differentiation. Cell. 1997;89(5):747-54.

10. Juge-Abury C, Pernin A, Favex T, Burger A, Wahl W, Meier CA, Desvergne B. DNA binding properties of peroxisome proliferators-activated receptor subtypes on various natural peroxisome proliferators response elements. J Biol Chem. 1997;272(40):25252-9.

11. Lehmann JM, Moore LB, Smith-Oliver TA, Wilkison WO, Willson TM, Kliewer SA. An antidiabetic thiazoladinedione is a high affinity ligand for peroxisome proliferator-activated receptor gamma (PPAR-gamma). J Biol Chem. 1995;270(22):12953-6.

12. Miyazaki Y, Glass L, Triplitt C, Matsuda M, Cusi K, Mahankali A, Mahankali S, Mandarino LJ, DeFronzo RA. Effect of rosiglitazone on glucose and nonesterified fatty acid metabolism in type II diabetic patients. Diabetologia. 2001;44(12):2210-9.
13. Fonseca $V$. Effect of thiazolidinediones on body weight in patients with diabetes mellitus. Am J Med. 2003;115(Suppl 8A):42S-8S.

14. Lecka-Czernik B, Gubrij I, Moerman EJ, Kajkenova O, Lipschitz DA, Manolagas SC, Jilka RL. Inhibition of Osf2/Cbfa1 expression and terminal osteoblast differentiation by PPARgamma2. J Cell Biochem. 1999;74(3):357-71.

15. Ali AA, Weinstein RS, Stewart SA, Parfitt AM, Manolagas SC, Jilka RL. Rosiglitazone causes bone loss in mice by suppressing osteoblast differentiation and bone formation. Endocrinology. 2005;146(3):1226-35.

16. Rzonca SO, Suva $\sqcup$, Gaddy D, Montague DC, Lecka-Czernik B. Bone is a target for the antidiabetic compound rosiglitazone. Endocrinology. 2004;145(1):401-6.

17. Bilik D, McEwen LN, Brown MB, Pomeroy NE, Kim C, Asao K, Crosson JC, Duru OK, Ferrara A, Hsiao VC, et al. Thiazolidinediones and fractures: evidence from translating research into action for diabetes. J Clin Endocrinol Metab. 2010;95(10):4560-5.

18. Zhu ZN, Jiang YF, Ding T. Risk of fracture with thiazolidinediones: an updated meta-analysis of randomized clinical trials. Bone. 2014;68:115-23.

19. Hallenborg P, Petersen RK, Kouskoumvekaki I, Newman JW, Madsen L, Kristiansen K. The elusive endogenous adipogenic PPARgamma agonists: lining up the suspects. Prog Lipid Res. 2016;61:149-62.

20. Wang L, Waltenberger B, Pferschy-Wenzig EM, Blunder M, Liu X, Malainer C, Blazevic T, Schwaiger S, Rollinger JM, Heiss EH, et al. Natural product agonists of peroxisome proliferator-activated receptor gamma (PPARgamma): a review. Biochem Pharmacol. 2014:92(1):73-89.

21. Choi JH, Banks AS, Estall JL, Kajimura S, Bostrom P, Laznik D, Ruas JL, Chalmers MJ, Kamenecka TM, Bluher M, et al. Anti-diabetic drugs inhibit obesity-linked phosphorylation of PPARgamma by Cdk5. Nature. 2010; 466(7305):451-6.

22. Kliewer SA, Sundseth SS, Jones SA. Fatty acids and eicosanoids regulate gene expression through direct interactions with peroxisome proliferatoractivated receptors $a$ and $\gamma$. Proc Natl Acad Sci U S A. 1997;94:4318-23.

23. Grun F, Watanabe H, Zamanian Z, Maeda L, Arima K, Cubacha R, Gardiner DM, Kanno J, Iguchi T, Blumberg B. Endocrine-disrupting organotin compounds are potent inducers of adipogenesis in vertebrates. Mol Endocrinol. 2006:20(9):2141-55.

24. Watt J, Schlezinger JJ. Structurally-diverse, PPARgamma-activating environmental toxicants induce adipogenesis and suppress osteogenesis in bone marrow mesenchymal stromal cells. Toxicology. 2015;331:66-77.

25. Feige JN, Gelman L, Rossi D, Zoete V, Metivier R, Tudor C, Anghel SI, Grosdidier A, Lathion C, Engelborghs Y, et al. The endocrine disruptor monoethyl-hexyl-phthalate is a selective peroxisome proliferator-activated receptor gamma modulator that promotes adipogenesis. J Biol Chem. 2007; 282(26):19152-66

26. Pomatto V, Cottone E, Cocci P, Mozzicafreddo M, Mosconi G, Nelson ER, Palermo FA, Bovolin P. Plasticizers used in food-contact materials affect adipogenesis in 3T3-L1 cells. J Steroid Biochem Mol Biol. 2018;178:322-32.

27. Pillai HK, Fang M, Beglov D, Kozakov D, Vajda S, Stapleton HM, Webster TF, Schlezinger JJ. Ligand binding and activation of PPARgamma by Firemaster(R) 550: effects on adipogenesis and osteogenesis in vitro. Environ Health Perspect. 2014;122(11):1225-32.

28. Riu A, Grimaldi M, le Maire A, Bey G, Phillips K, Boulahtouf A, Perdu E, Zalko D, Bourguet W, Balaguer P. Peroxisome proliferator-activated receptor gamma is a target for halogenated analogs of bisphenol a. Environ Health Perspect. 2011;119(9):1227-32.

29. Pereira-Fernandes $A$, Demaegdt $H$, Vandermeiren $K$, Hectors $T L$, Jorens $P G$, Blust R, Vanparys C. Evaluation of a screening system for obesogenic compounds: screening of endocrine disrupting compounds and evaluation of the PPAR dependency of the effect. PLoS One. 2013;8(10):e77481.

30. Feige JN, Gerber A, Casals-Casas C, Yang Q, Winkler C, Bedu E, Bueno M, Gelman L, Auwerx J, Gonzalez FJ, et al. The pollutant diethylhexyl phthalate regulates hepatic energy metabolism via species-specific PPARalphadependent mechanisms. Environ Health Perspect. 2010;118(2):234-41.

31. Bertuloso BD, Podratz PL, Merlo E, de Araujo JF, Lima LC, de Miguel EC, de Souza LN, Gava AL, de Oliveira M, Miranda-Alves L, et al. Tributyltin chloride leads to adiposity and impairs metabolic functions in the rat liver and pancreas. Toxicol Lett. 2015;235(1):45-59.

32. Penza M, Jeremic M, Marrazzo E, Maggi A, Ciana P, Rando G, Grigolato PG Di Lorenzo D. The environmental chemical tributyltin chloride (TBT) shows both estrogenic and adipogenic activities in mice which might depend on the exposure dose. Toxicol Appl Pharmacol. 2011;255(1):65-75.

33. Green AJ, Graham JL, Gonzalez EA, La Frano MR, Petropoulou SE, Park JS, Newman JW, Stanhope KL, Havel PJ, La Merrill MA: Perinatal triphenyl 
phosphate exposure accelerates type 2 diabetes onset and increases adipose accumulation in UCD-type 2 diabetes mellitus rats. Reproductive toxicology (Elmsford, NY 2017, 68:119-129.

34. Watt J, Baker AH, Meeks B, Pajevic PD, Morgan EF, Gerstenfeld LC, Schlezinger JJ. Tributyltin induces distinct effects on cortical and trabecular bone in female C57BI/6J mice. J Cell Physiol. 2018.

35. Yan $\mathrm{H}$, Hales BF. Effects of organophosphate ester flame retardants on endochondral ossification in ex vivo murine limb bud cultures. Toxicol Sci. 2018.

36. Chiu CY, Sun SC, Chiang CK, Wang CC, Chan DC, Chen HJ, Liu SH, Yang RS Plasticizer di(2-ethylhexyl)phthalate interferes with osteoblastogenesis and adipogenesis in a mouse model. J Orthop Res. 2018;36(4):1124-34.

37. Kannan K, Senthilkumar K, Giesy JP. Occurence of butyltin compounds in human blood. Environ Sci Technol. 1999;33:1776-9.

38. Hoffman K, Butt CM, Webster TF, Preston EV, Hammel SC, Makey C, Lorenzo AM, Cooper EM, Carignan C, Meeker JD, et al. Temporal trends in exposure to organophosphate flame retardants in the United States. Environ Sci Technol Lett. 2017:4(3):112-8.

39. Varshavsky JR, Morello-Frosch R, Woodruff TJ, Zota AR. Dietary sources of cumulative phthalates exposure among the U.S. general population in NHANES 2005-2014. Environ Int. 2018;115:417-29.

40. Moon HB, Lee DH, Lee YS, Kannan K. Occurrence and accumulation patterns of polycyclic aromatic hydrocarbons and synthetic musk compounds in adipose tissues of Korean females. Chemosphere. 2012:86(5):485-90.

41. Carignan CC, Abdallah MA, Wu N, Heiger-Bernays W, McClean MD, Harrad S, Webster TF. Predictors of tetrabromobisphenol-a (TBBP-A) and hexabromocyclododecanes (HBCD) in milk from Boston mothers. Environ Sci Technol. 2012;46(21):12146-53.

42. Watt J, Webster TF, Schlezinger JJ. Generalized concentration addition modeling predicts mixture effects of environmental PPARgamma agonists. Toxicol Sci. 2016.

43. Murk AJ, Legler J, Denison MS, Giesy JP, van de Guchte C, Brouwer A. Chemical-activated luciferase gene expression (CALUX): a novel in vitro bioassay for ah receptor active compounds in sediments and pore water. Fundam Appl Toxicol. 1996:33(1):149-60.

44. Windal I, Denison MS, Birnbaum LS, Van Wouwe N, Baeyens W, Goeyens L. Chemically activated luciferase gene expression (CALUX) cell bioassay analysis for the estimation of dioxin-like activity: critical parameters of the CALUX procedure that impact assay results. Environ Sci Technol. 2005; 39(19):7357-64.

45. Van Wouwe N, Windal I, Vanderperren H, Eppe G, Xhrouet C, Massart AC, Debacker N, Sasse A, Baeyens W, De Pauw E, et al. Validation of the CALUX bioassay for PCDD/F analyses in human blood plasma and comparison with GC-HRMS. Talanta. 2004;63(5):1157-67.

46. Pauwels A, Cenijn PH, Schepens PJ, Brouwer A. Comparison of chemicalactivated luciferase gene expression bioassay and gas chromatography for PCB determination in human serum and follicular fluid. Environ Health Perspect. 2000;108(6):553-7.

47. Schlezinger JJ, Bernard PL, Haas A, Grandjean P, Weihe P, Sherr DH. Direct assessment of cumulative aryl hydrocarbon receptor agonist activity in sera from experimentally exposed mice and environmentally exposed humans. Environ Health Perspect. 2010;118(5):693-8.

48. Gijsbers L, Man HY, Kloet SK, de Haan LH, Keijer J, Rietjens IM, van der Burg B, Aarts JM. Stable reporter cell lines for peroxisome proliferator-activated receptor gamma (PPARgamma)-mediated modulation of gene expression. Anal Biochem. 2011:414(1):77-83.

49. Ziccardi M, Gardner I, Denison M. Development and modification of a recombinant cell bioassay to directly detect halogenated and polycyclic aromatic hydrocarbons in serum. Toxicol Sci. 2000;54:183-93.

50. Pliskova M, Vondracek J, Canton RF, Nera J, Kocan A, Petrik J, Trnovec T, Sanderson T, van den Berg M, Machala M. Impact of polychlorinated biphenyls contamination on estrogenic activity in human male serum. Environ Health Perspect. 2005;113(10):1277-84

51. Schulman IG, Shao G, Heyman RA. Transactivation by retinoid X receptorperoxisome proliferators-activated receptor (PPAR $\gamma$ ) heterodimers: intermolecular synergy requires only the PPARY hormone-dependent activation function. Mol Cell Biol. 1998;18:3483-94.

52. Rao MN, Mullangi R, Katneni K, Ravikanth B, Babu AP, Rani UP, Naidu MU, Srinivas NR, Rajagopalan R. Lack of effect of sucralfate on the absorption and pharmacokinetics of rosiglitazone. J Clin Pharmacol. 2002;42(6):670-5.

53. Cox PJ, Ryan DA, Hollis FJ, Harris AM, Miller AK, Vousden M, Cowley H. Absorption, disposition, and metabolism of rosiglitazone, a potent thiazolidinedione insulin sensitizer, in humans. Drug Metab Dispos. 2000; 28(7):772-80.

54. Gurnell M, Wentworth JM, Agostini M, Adams M, Collingwood TN, Provenzano C, Browne PO, Rajanayagam O, Burris TP, Schwabe JW, et al. A dominant-negative peroxisome proliferator-activated receptor gamma (PPARgamma) mutant is a constitutive repressor and inhibits PPARgammamediated adipogenesis. J Biol Chem. 2000;275(8):5754-9.

55. Kim JB, Wright HM, Wright M, Spiegelman BM. ADD1/SREBP1 activates PPARgamma through the production of endogenous ligand. Proc Natl Acad Sci U S A. 1998;95(8):4333-7.

56. Rajapakse N, Silva E, Scholze M, Kortenkamp A. Deviation from additivity with estrogenic mixtures containing 4-nonylphenol and 4-tert-octylphenol detected in the E-SCREEN assay. Environ Sci Technol. 2004;38(23):6343-52.

57. Mangelsdorf DJ, Borgmeyer U, Heyman RA, Zhou JY, Ong ES, Oro AE, Kakizuka A, Evans RM. Characterization of three RXR genes that mediate the action of 9-cis retinoic acid. Genes Dev. 1992;6(3):329-44.

58. Bradford MM. A rapid and sensitive method for the quantitation of microgram quantities of protein utilizing the principle of protein-dye binding. Anal Biochem. 1976;72:248-54.

59. Kojetin DJ, Matta-Camacho E, Hughes TS, Srinivasan S, Nwachukwu JC, Cavett V, Nowak J, Chalmers MJ, Marciano DP, Kamenecka TM, et al. Structural mechanism for signal transduction in RXR nuclear receptor heterodimers. Nat Commun. 2015;6:8013.

60. Jpenberg A, Tan NS, Gelman L, Kersten S, Seydoux J, Xu J, Metzger D, Canaple L, Chambon P, Wahli W, et al. In vivo activation of PPAR target genes by RXR homodimers. EMBO J. 2004;23(10):2083-91.

61. Boehm MF, Zhang L, Zhi L, McClurg MR, Berger E, Wagoner M, Mais DE, Suto CM, Davies JA, Heyman RA, et al. Design and synthesis of potent retinoid $X$ receptor selective ligands that induce apoptosis in leukemia cells. J Med Chem. 1995:38(16):3146-55.

62. Hestermann EV, Stegeman JJ, Hahn ME. Serum alters the uprake and relative potencies of halogenated aromatic hydrocarbons in cell culture bioassays. Toxicol Sci. 2000;53(2):316-25.

63. Ahmadian M, Suh JM, Hah N, Liddle C, Atkins AR, Downes M, Evans RM. PPARgamma signaling and metabolism: the good, the bad and the future. Nat Med. 2013;19(5):557-66.

64. Fajas L, Auboeuf D, Raspe E, Schoonjans K, Lefebvre A-M, Saladin R, Najib J, Laville M, Fruchart JC, Deeb S, et al. The organization, promoter analysis and expression of the human PPARy gene. J Biol Chem. 1997;272(30):18779-89.

65. Vidal-Puig A, Jimenez-Linan M, Lowell BB, Hamann A, Hu E, Spiegelman B, Flier JS, Moller DE. Regulation of PPAR gamma gene expression by nutrition and obesity in rodents. J Clin Invest. 1996;97(11):2553-61.

66. Avandia Perscribing Information [https://www.fda.gov/media/75754/ download].

67. Gijsbers L, van Eekelen HD, de Haan LH, Swier JM, Heijink NL, Kloet SK, Man HY, Bovy AG, Keijer J, Aarts JM, et al. Induction of peroxisome proliferator-activated receptor gamma (PPARgamma)-mediated gene expression by tomato (Solanum lycopersicum L.) extracts. J Agric Food Chem. 2013;61(14):3419-27.

68. Suzuki G, Tue NM, Malarvannan G, Sudaryanto A, Takahashi S, Tanabe S, Sakai S, Brouwer A, Uramaru N, Kitamura S, et al. Similarities in the endocrine-disrupting potencies of indoor dust and flame retardants by using human osteosarcoma (U2OS) cell-based reporter gene assays. Environ Sci Technol. 2013;47(6):2898-908.

69. Fang M, Webster TF, Stapleton HM. Activation of human peroxisome proliferator-activated nuclear receptors (PPARgamma1) by semi-volatile compounds (SVOCS) and chemical mixtures in indoor dust. Environ Sci Technol. 2015;49(16):10057-64.

70. Kassotis CD, Nagel SC, Stapleton HM. Unconventional oil and gas chemicals and wastewater-impacted water samples promote adipogenesis via PPARgamma-dependent and independent mechanisms in 3T3-L1 cells. Sci Total Environ. 1601-1610;2018:640-1.

71. Szeles L, Poliska S, Nagy G, Szatmari I, Szanto A, Pap A, Lindstedt M, Santegoets SJ, Ruhl R, Dezso B, et al. Research resource: transcriptome profiling of genes regulated by RXR and its permissive and nonpermissive partners in differentiating monocyte-derived dendritic cells. Mol Endocrinol. 2010;24(11):2218-31.

72. Stafslien DK, Vedvik KL, De Rosier T, Ozers MS. Analysis of ligand-dependent recruitment of coactivator peptides to RXRbeta in a time-resolved fluorescence resonance energy transfer assay. Mol Cell Endocrinol. 2007;264(1-2):82-9.

73. Buchinger S, Spira D, Broder K, Schlusener M, Ternes T, Reifferscheid G. Direct coupling of thin-layer chromatography with a bioassay for the 
detection of estrogenic compounds: applications for effect-directed analysis. Anal Chem. 2013;85(15):7248-56.

74. Fang M, Webster TF, Ferguson PL, Stapleton HM. Characterizing the peroxisome proliferator-activated receptor (PPARgamma) ligand binding potential of several major flame retardants, their metabolites, and chemical mixtures in house dust. Environ Health Perspect. 2015;123(2):166-72.

75. Qiang L, Wang L, Kon N, Zhao W, Lee S, Zhang Y, Rosenbaum M, Zhao Y, Gu W, Farmer SR, et al. Brown remodeling of white adipose tissue by SirT1dependent deacetylation of Ppargamma. Cell. 2012;150(3):620-32.

76. Kim S, Li A, Monti S, Schlezinger JJ. Tributyltin induces a transcriptional response without a brite adipocyte signature in adipocyte models. Arch Toxicol. 2018.

77. Kim S, Reed E, Monti S, Schlezinger JJ. Development of a classification taxonomy for Adipogenic chemicals: a novel tool for identifying emerging metabolic health threats. Environ Health Perspect. 2019; Submitted for publication:BIORXIV 519629.

- fast, convenient online submission

- thorough peer review by experienced researchers in your field

- rapid publication on acceptance

- support for research data, including large and complex data types

- gold Open Access which fosters wider collaboration and increased citations

- maximum visibility for your research: over $100 \mathrm{M}$ website views per year

At BMC, research is always in progress.

Learn more biomedcentral.com/submissions 